\title{
Carbohydrate-Specific Human Heterophile Antibodies in Normal Human Sera That React with Xenogeneic Cells
}

\author{
R. Laus, K. Ulrichs, W. Müller-Ruchholtz \\ Department of Immunology, University of Kiel, FRG
}

\begin{abstract}
Human heterophile antibodies (HHA) that are present in normal human sera (NHS) play an important role in hyperacute xenograft rejection. The aim of this study was to analyze the occurrence, mode of action and molecular specificity of HHA in NHS that are directed against xenogeneic lymphocytes (isolated from mouse, rat, guinea pig, rabbit, cattle and pig) and isolated rat pancreatic islets. All sera contained variable amounts of HHA that killed the target cells via the classical complement pathway. The cytotoxic activity of these HHA was specifically inhibited by certain carbohydrates $(\alpha-D$-melibiose, $\beta$-lactose, $\beta$-gentiobiose, $\beta$-cellobiose, $D$-mannose, $\mathrm{N}$-acetyl- $\beta$ - $D$-mannosamine and $\alpha$ - $D$-rhamnose) and by rat IgM. By means of affinity chromatography with immobilized inhibitors we obtained an antibody preparation of mainly IgG type from NHS (up to $3.5 \mathrm{mg} / 10 \mathrm{ml}$ serum) that reacted strongly with rat lymphocytes and isolated rat pancreatic islets. Though thus far residual xenospecific antibody activity has remained in the sera even after multiple affinity chromatography, these data suggest that specific elimination of HHA is feasible and that it may be thus possible to overcome a major obstacle to xenotransplantation.
\end{abstract}

\section{Introduction}

Heterophile antibodies are antibodies that react with antigens with which the producing organism has not been immunized. That human heterophile antibodies (HHA) occur in normal human sera (NHS) has been known at least since Ehrlich and Morgenroth discovered the $\mathrm{ABO}$ isohemagglutinins [1].

Much attention has been paid to HHA that appear under various pathological conditions, such as infectious mononucleosis [2], serum sickness [3, 4], Kawasaki's disease [5], various malignancies [6], renal allotransplantation [6] and many others.

One field in which heterophile antibodies present in normal sera play an important role is xenotransplantation among more distantly related species, where grafts are usually rejected in a hyperacute fashion. Most authors assume that HHA in NHS trigger hyperacute xenograft rejection [7-13], while a few other authors [14] hold that direct antibody-independent activation of the alternate pathway of complement on the surface of xenogeneic target cells plays the main role in serum-mediated xenocytotoxicity. Attempts to avoid hyperacute xenograft rejection by means of plasmapheresis yielded only meager results $[13,15,16]$, other attempts none. Thus far there appears to have been no really thorough analysis of the occurrence, cytotoxic mechanism and molecular specificity of xenocytotoxic HHA in NHS. For instance, in spite of the increasing interest in xenotransplantation of isolated pancreatic islets, there are no data available on the role of heterophile antibodies in hyperacute xenograft rejection. This obvious lack led us to perform the study reported in this paper.

\section{Material and Methods}

\section{Stock Solutions}

The following stock solutions were used: 0.1 M EDTA (ethylene diamine tetraacetic acid), $0.1 M$ EGTA (ethylene glycol-bis-( $\beta$-aminoethyl ether)-N,N,N,' $\mathrm{N}^{\prime}$-tetraacetic acid), $0.2 \mathrm{M} \mathrm{CaCl}_{2}, 0.2 \mathrm{M}$ $\mathrm{MgCl}_{2}, 300 \mathrm{mM} \alpha$-melibiose, $\beta$-lactose, $\beta$-gentiobiose, $\beta$-cellobiose, $D$-mannose, $\mathrm{N}$-acetyl- $\beta$ - $D$-mannosamine, $\alpha$-rhamnose, $D$-glucose, saccharose, $10 \mathrm{~m} M$ dextran 10,000 . 
Table I. Mechanism of xenocytotoxicity of NHS

Treatment of serum

\begin{tabular}{llllll}
\hline $\begin{array}{l}\text { medium } \\
\text { (no serum) }\end{array}$ & serum & $\begin{array}{l}56^{\circ} \mathrm{C} \\
30 \mathrm{~min}\end{array}$ & $\begin{array}{l}50^{\circ} \mathrm{C} \\
15 \mathrm{~min}\end{array}$ & $\begin{array}{l}0.01 \mathrm{M} \mathrm{EGTA} \\
0.05 \mathrm{M} \mathrm{Mg}\end{array}$ & $\begin{array}{l}0.01 \mathrm{M} \text { EGTA } \\
0.01 \mathrm{M} \mathrm{Ca}\end{array}$ \\
\hline 10 & 98 & 10 & 98 & 10 & 98 \\
$(5-15)$ & $(96-100)$ & $(5-15)$ & $(96-100)$ & $(5-15)$ & $(96-100)$
\end{tabular}

Identical results were obtained with 15 individual NHS, which were tested with 4 different lymphocyte preparations each of 6 different target species.

\section{Serum Samples}

Blood samples from normal adult donors were allowed to clot for $3 \mathrm{~h}$ at room temperature. The sera were used immediately or after freezing at $-80^{\circ} \mathrm{C}$ for 3 months or less.

\section{Single Cell Preparations}

Lymphocytes were obtained from heparinized peripheral blood from pig, cattle and rabbit by using Ficoll-Hypaque gradient centrifugation. They were washed $(3 \times)$ and suspended at a concentration of $2 \times 10^{6}$ cells $/ \mathrm{ml}$ in RPMI 1640 medium. Lymph node cell suspensions were prepared from guinea pig, rat and mouse by passing the excised nodes through a nylon net. Cells were washed and suspended in RPMI as above.

\section{Rat Pancreatic Islets}

Islets were isolated and purified by collagenase digestion, Ficoll density gradient centrifugation and handpicking under a dissecting microscope using the green filter light technique [17].

\section{Lymphocytotoxicity Test (LCT)}

The method of Terasaki and McClelland [18] was used in two modified versions: (1) A 1- $\mu$ l cell suspension was incubated with $5 \mu \mathrm{l}$ fresh serum in a twofold dilution series for $2 \mathrm{~h}$ in microtest plates. Then $3.3 \mu \mathrm{l}$ eosin and $6.6 \mu \mathrm{l} 10 \%$ formalin were added per well. The percentage of dead cells was determined by means of phase contrast microscopy. Titers give the dilutions at which approximately $50 \%$ of the cells were killed. (2) The same procedure was followed, except that heat-inactivated human serum was used and after $1 \mathrm{~h}$ of incubation $5 \mu \mathrm{l}$ of fresh normal rat serum was added as complement source.

\section{Immunofluorescence Assays}

Single cell suspensions were stained with a standard method on microtest plates. Intact rat pancreatic islets were stained according to the method of Ulrichs and Müller-Ruchholtz [19]. Briefly, about 150 islets were suspended in $100 \mu \mathrm{l}$ of serum for $30 \mathrm{~min}$ at $24^{\circ} \mathrm{C}$ in siliconized glass tubes. After washing $100 \mu \mathrm{l}$ anti-human Ig, FITC was added and incubation was performed at $4{ }^{\circ} \mathrm{C}$ for $30 \mathrm{~min}$ in the dark. About 20 islets in $10 \mu \mathrm{l}$ veronal buffer were transferred with a Pasteur pipette onto standard microscopic glass slides. A cover slide was placed on top. Thus, the islets remained undamaged and their genuine three-dimensional infrastructure appeared nearly two-dimensional, facilitating vertical screening. Each of the ten glass slides in one experiment was thoroughly screened for fluorescent islet cells with an inverted light fluorescence microscope.

\section{Affinity Chromatography Methods}

Cellobiose, gentiobiose, lactose and melibiose were each coupled to $6 \mathrm{ml}$ epoxy-activated Sepharose $6 \mathrm{~B}$ in $10 \mathrm{mM} \mathrm{NaOH}$ at a concentration of $40 \mathrm{mg} / \mathrm{ml}$. Mannose, rhamnose, and $\mathrm{N}$-acetylmannosamine were each coupled to $6 \mathrm{ml}$ epoxy-activated Sepharose $6 \mathrm{~B}$ in $10 \mathrm{mM} \mathrm{NaOH}$ at a concentration of $20 \mathrm{mg} / \mathrm{ml}$ under normal conditions [20]. $50 \mathrm{mg}$ rat IgM obtained through affinity chromatography on protamine Sepharose, followed by Sephacryl S300 gel filtration [21], were coupled to $7 \mathrm{ml} \mathrm{CNBr-activated} \mathrm{Se-}$ pharose $4 \mathrm{~B}$ in carbonate buffer, $\mathrm{pH} 8.3$, under normal conditions [20]. Gels were packed into chromatography columns. $10 \mathrm{ml}$ serum was passed through the columns with a flow rate of $15 \mathrm{ml} / \mathrm{h}$. They were washed until UV monitoring at $280 \mathrm{~nm}$ detected no desorbing protein. The fall-through fraction was collected and readjusted to the original volume with ultrafiltration. Bound material was eluted with citrate buffer, $\mathrm{pH} 2.5$, and collected in $0.6 \mathrm{M}$ carbonate buffer, pH 9.6. It was dialyzed against PBS $(3 \times)$ for $24 \mathrm{~h}$. Eluates were characterized by using a double immunodiffusion technique (antisera: rabbit anti-human IgM, rabbit anti-human IgG, goat anti-human agammaglobulinemic serum components). The protein content of antibody preparations was roughly calculated by UV photometry at $280 \mathrm{~nm}$.

\section{Results}

\section{Mechanism of Xenolymphocytotoxicity of NHS}

In a first set of studies we examined the cytotoxicity of 30 NHS toward lymphocytes of mouse, rat, guinea pig, rabbit, pig and cow by LCT 1 . The cytotoxicity showed a random distribution with lack of species preference. No dependence on, e.g., target species or the ABO group of the serum donor was seen. 15 of these sera, which, undiluted, killed nearly $100 \%$ target cells from all 6 target species, were chosen for analysis of the mode of xenocytotoxic action. Table I shows that when the serum is treated in ways that should still allow activation of the alternate complement pathway (e.g., chelation of $\mathrm{Ca}$ with EGTA in the presence of a high $\mathrm{Mg}$ concentration) cytotoxicity is completely abolished. In contrast, 
heating $\left(50^{\circ} \mathrm{C}, 15 \mathrm{~min}\right)$ which should preferentially inactivate the alternate pathway did not result in a loss of cytotoxicity. Only when classical complement activation was allowed, was cytotoxicity seen.

\section{Role of the Complement Source}

To determine whether the established LCT with heated $\left(56^{\circ} \mathrm{C}, 30 \mathrm{~min}\right)$ sera and xenogeneic complement source is useful for analyzing of HHA we proceeded as follows: the cytotoxicity of 18 sera to rat and pig lymphocytes was examined in parallel tests without and with rat normal serum as complement source (LCT 1 and LCT 2, see above). While the results of both LCT were comparable when the target was pig lymphocytes, LCT 2 always showed lower titers with the target rat lymphocytes than LCT 1 (table II). Other experiments clearly showed that LCT 2 always resulted in lower titers when complement source and target cells were from the same species (data not shown).

\section{Xenoreactivity of HHA in NHS with Rat Pancreatic} Islets

Table III shows the reactivity of HHA with intact rat pancreatic islets, as detected by means of an immunofluorescence technique. All sera tested contained HHA that reacted with one substructure or the other of the islets. As table III shows, HHA reacted mainly with connective tissue and vascular endothelium. 7/10 NHS contained HHA that were directed against the endocrine cells of rat pancreatic islets. Inhibition studies with carbohydrates and affinity chromatography with immobilized inhibitors yielded similar results as were obtained with lymphocytes (see below). In addition, islets that were preincubated with NHS produced significantly less insulin in in vitro cultures than untreated islets (data not shown).

\section{Molecular Specificity of $\mathrm{HHA}$}

In order to investigate the molecular specificity of HHA in NHS we performed the following inhibition assays: solutions of inhibitors were added to the test sera at room temperature $1 \mathrm{~h}$ before further testing. One respresentative example out of four inhibition studies is shown in table IV. The results can be summarized as follows: dextran 10,000 , glucose and saccharose do not have any effect on the original titers. The other carbohydrates showed varying inhibitory activity, dependent on the concentration and the target species. This was not due to anticomplementary
Table II. Cytotoxic titers of 18 NHS for xenogeneic lymphocytes without (LCT1) and with (LCT2) rat normal serum as complement source

Serum No.

$\begin{array}{llllllllllllllllll}1 & 2 & 3 & 4 & 5 & 6 & 7 & 8 & 9 & 10 & 11 & 12 & 13 & 14 & 15 & 16 & 17 & 18\end{array}$

Rat lymphocytes

$\begin{array}{lllllllllllllllllll}\text { LCT1 } & 1 & 0 & 8 & 2 & 16 & 8 & 8 & 4 & 2 & 8 & 0 & 2 & 8 & 8 & 8 & 8 & 1 & 0\end{array}$

$\begin{array}{lllllllllllllllllll}\text { LCT2 } & 0 & 0 & 0 & 2 & 1 & 1 & 0 & 0 & 0 & 0 & 0 & 0 & 2 & 1 & 1 & 0 & 0 & 0\end{array}$

Pig lymphocytes

$\begin{array}{lllllllllllllllllll}\text { LCT1 } & 1 & 0 & 16 & 8 & 16 & 8 & 4 & 8 & 2 & 4 & 0 & 8 & 16 & 16 & 16 & 8 & 4 & 0\end{array}$

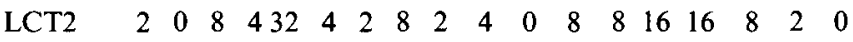

activity of the carbohydrates as was assured by using sera containing the carbohydrates as complement source for a cytotoxic rabbit anti-rat lymphocyte serum. No anticomplementary activity was seen. In the 4 sera tested, melibiose, the best inhibitor, showed inhibitory activity at a concentration of $1.5 \mathrm{~m} \mathrm{M}$ in $4 / 24$ cases, at a concentration of $15 \mathrm{mM}$ in $12 / 24$ cases and at a concentration of $150 \mathrm{mM}$ in $16 / 24$ cases. The maximum titer reduction was 5 titer steps. The individual sera yielded different results. The incidence of inhibition ranged from 19/144 cases up to $55 / 144$ cases. Inhibition varied, depending on target species: cytotoxicity toward mouse lymphocytes was inhibited in $2 / 96$ cases, toward cattle and pig lymphocytes in $23 / 96$ cases, toward rabbit lymphocytes in $26 / 96$ cases, and toward rat lymphocytes in $41 / 96$ cases. Rat IgM $(1 \mathrm{mg} / \mathrm{ml})$ completely inhibited cytotoxicity of NHS toward rat lymphocytes.

\section{Isolation of HHA by Means of Affinity Chromatography}

In this section we examined whether it is possible to eliminate xenospecific HHA from NHS with immobilized inhibitors. Approaches using Sepharose columns with only one immobilized sugar yielded small amounts of isolated antibodies and had no detectable effect on the HHA content of NHS. The most successful approach was sequential adsorption to two Sepharose columns: all seven saccharides that produced positive results in inhibition studies were coupled to one of them, rat IgM was coupled to the other. Table V summarizes the results: $1.0-3.5 \mathrm{mg}$ anti- 
Table III. HHA in NHS that react with rat pancreatic islets shown by an immunofluorescence method using intact islets

\begin{tabular}{|c|c|c|c|c|c|c|c|c|c|c|}
\hline & \multicolumn{10}{|c|}{ Serum no. } \\
\hline & 1 & 2 & 4 & 5 & 8 & 10 & 19 & 20 & 22 & 23 \\
\hline Vascular endothelium & ++ & +++ & ++++ & ++ & +++ & + & ++++ & ++++ & ++++ & ++ \\
\hline Connective tissue fibers & ++ & +++ & +++ & ++ & +++ & + & ++++ & +++ & $+++t$ & ++ \\
\hline
\end{tabular}
cence.

Fluorescence was graded by its intensity: $++++=$ very strong; $+++=$ strong; $++=$ medium; $+=$ weak; $0=$ no detectable fluores-

Table IV. Reduction of cytotoxicity of one NHS (No. 19) by various carbohydrates: results are expressed as reciprocal titers obtained with LCT1

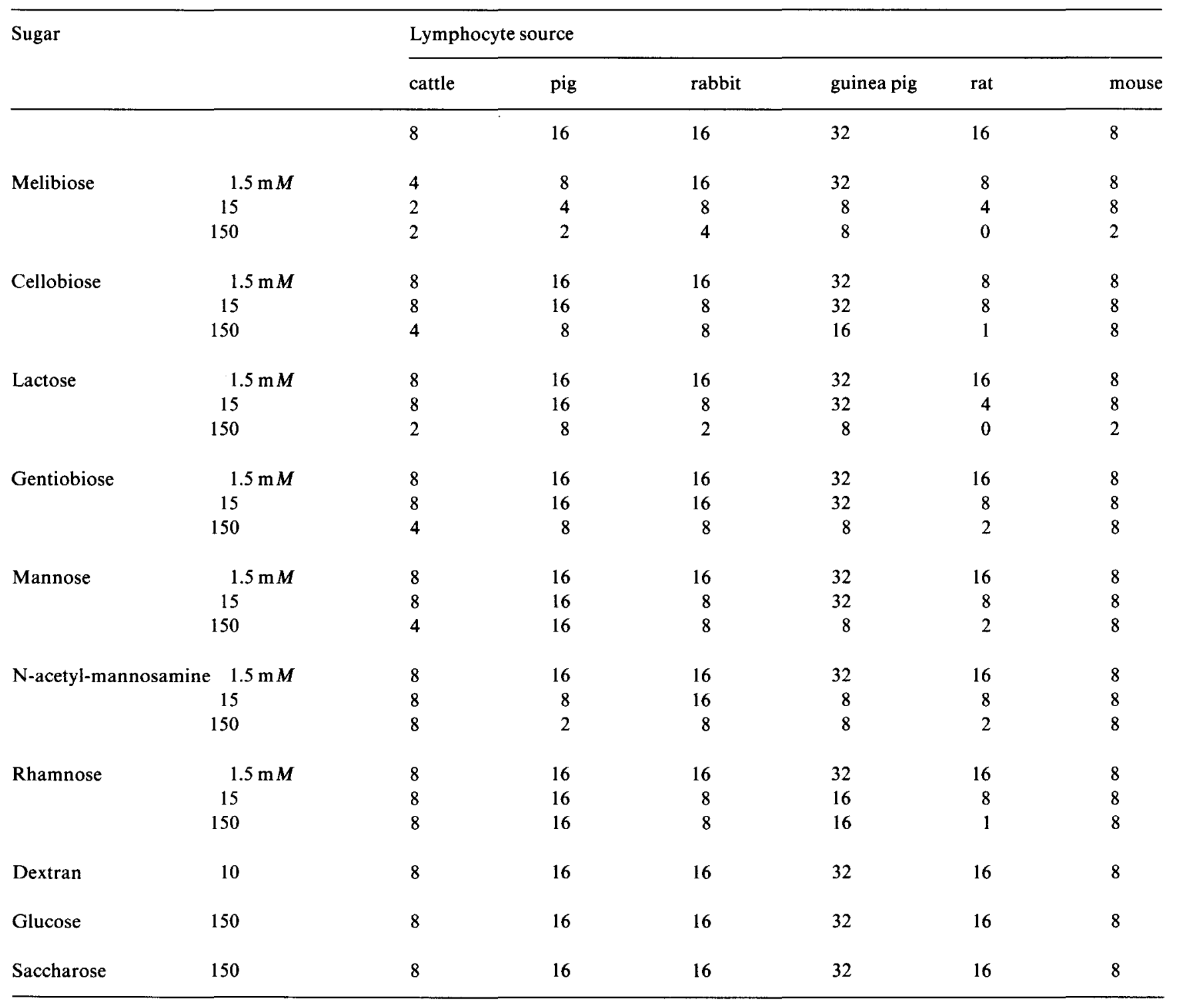


Table V. Isolation of HHA from NHS with immobilized inhibitors

\begin{tabular}{|c|c|c|c|c|c|}
\hline \multirow[t]{2}{*}{ Serum No. } & \multirow{2}{*}{$\begin{array}{l}\text { Protein yield/ } \\
10 \mathrm{ml} \text { serum }\end{array}$} & \multicolumn{4}{|l|}{ Reactivity with } \\
\hline & & anti-human Ig & anti-human IgG & anti-human IgM & anti-human aggs \\
\hline 20 & $3.0 / 1.5 \mathrm{mg}$ & +++ & +++ & + & $(+)$ \\
\hline 21 & $3.0 / 1.0 \mathrm{mg}$ & +++ & +++ & + & $(+)$ \\
\hline
\end{tabular}

aggs = agammaglobulinemic serum proteins.

First result was obtained by affinity chromatography with the 7 carbohydrates that were efficient in inhibition studies attached to Sepharose. Second result was obtained by affinity chromatography with rat IgM attached to Sepharose.

bodies $/ 10 \mathrm{ml} \mathrm{NHS}$ were isolated. In double immunodiffusion studies it was shown that this preparation yielded predominantly IgG.

\section{Reactivity of Isolated Antibodies}

All isolated antibodies reacted with rat lymphocytes and with isolated rat pancreatic islets at a concentration of $1 \mathrm{mg} / \mathrm{ml}$, as shown by means of indirect immunofluorescence.

\section{Decrease in HHA Levels in NHS after Affinity Chromatography}

HHA levels for rat lymphocytes were studied by means of immunofluorescence in 4 sera before and after affinity chromatography. The highest serum dilution at which antibodies were detected on the cell surface decreased in all 4 sera from 32 to 8 . This indicates that some but not all HHA that are specific for rat lymphocytes, were eliminated by affinity chromatography with immobilized inhibitors.

\section{Discussion}

The occurrence of carbohydrate antigens in heterophile systems was characterized succinctly by Kano and Milgrom [22]: 'One is tempted to say that protein antigens behave "with dignity" in following the evolutionary pathway of development. The carbohydrates are those antigens that "play tricks" appearing in an unpredictable way.'

It has often been presumed that HHA are carbohydrate-specific due to carbohydrate antigens shared between mammalian cells, microbes and plants [23, 24]. We made the very compatible finding that xeno- lymphocytotoxic HHA in NHS are inhibited by a variety of carbohydrates. Antibodies in NHS directed against the carbohydrates we used have already been described in other contexts [25-28], but, to the best of our knowledge, inhibition of xenocytotoxic HHA in NHS by carbohydrates has not been shown before.

Some heterophile antibodies in normal sera, such as in rabbit serum [29] and guinea pig serum [30], have been inhibited by various low molecular weight carbohydrates. Concerning NHS, such inhibition studies were successful when neuraminidase-treated human lymphocytes were used as target [31]. It can be questioned, however, whether the sugars with inhibitory activity are part of the cellular antigen to which they inhibit binding (which should be self-evident), since Milgrom's and Swieczynka's [32] recent discovery that 'natural' antibodies (e.g., HHA in NHS) may be multispecific, i.e., one single antibody may bind two distinct epitopes the same time. Thus, inhibition could occur through steric hindrance. That it is, in principle, possible to isolate carbohydrate-specific antibodies out of NHS was first shown by Sela et al. [33]. Our attempts to eliminate HHA directed against xenogeneic cells from NHS with immobilized inhibitors were partially successful. Affinity chromatography eliminated some, but not all HHA that reacted with rat lymphocytes. These results may be explained as follows: the heterogenous population of HHA consists partly of carbohydrate-specific antibodies. Some of these have high affinity for low molecular weight carbohydrates and can be isolated by affinity chromatography. Others can be inhibited by high sugar concentration (i.e., $150 \mathrm{~m} \mathrm{M}$ ), but their affinity is too low for successful affinity chromatography. This assumption is supported by the unusual finding that the affin- 
ity-isolated HHA were mainly of IgG type, though HHA are generally believed to be mainly of IgM type. Thus it is possible that these HHA of IgM type were found in the fall-through fractions after affinity chromatography because of their low affinity for the inhibitors.

The particular HHA that we studied are cytotoxic toward xenogeneic lymphocytes via the classical complement pathway. In other published attempts at analyzing the xenocytotoxicity of NHS, other mechanisms have also been described. These include antibody-independent activation of the alternate complement pathway at the surface of xenogeneic target cells $[14,34,35]$ and parallel action of both antibody-independent activation of alternate complement pathway and antibody-dependent activation of the classical complement pathway [36]. These different results can be explained by the choice of target cells and by differences in the experimental systems.

The practical relevance of heterophile antibodies in normal sera in hyperacute xenograft rejection has often been shown: in experimental renal xenotransplantation large immunoglobulin deposits of host origin were always found in hyperacutely rejected organs $[8-13,16]$. Thus, the elimination of xenospecific HHA from NHS remains a basic requirement for the successful abolition of hyperacute xenograft rejection. For this purpose, our studies present a method with a principle that may be useful. However, to be able to thoroughly eliminate all xenospecific HHA from NHS we need more knowledge of the structure of the pertinent antigens.

\section{References}

1 Ehrlich, P.; Morgenroth, J.: Über Haemolysine. 6. Mitt. Berl. klin. Wschr. 38: 569-574, 598-604 (1901).

2 Paul, J.R.; Bunnell, W.W.: The presence of heterophile antibodies in infectious mononucleosis. Am. J. med. Sci. 183: 90-104 (1932).

3 Kano, K.; Merrick, J.M.; Milgrom, F.: Classification of human heterophile antibodies. Int. Archs Allergy appl. Immun. 73: 373-377 (1984).

4 Hanganutziu, M.: Hẻmagglutines hétérogénétiques après injection des serum de cheval. C.r. Séanc. Soc. Biol. 91: 1457-1459 (1924).

5 Tagiguchi, M.; Tamura, T.; Goto, M.; Kusakawa, S.; Milgrom, F.; Kano, K.: Immunological studies on Kawasaki disease. I. Appearance of Hanganutziu-Deicher antibodies. Clin. exp. Immunol. 56: 345-352 (1984).

6 Milgrom, F.; Kano, K.; Fjelde, A.; Bloom, M.L.: Heterophile antigens and antibodies in transplantation and tumors; in Mur- phy, Cancer and transplantation, pp. 63-70 (Grune \& Stratton, New York 1975).

7 Perper, R.J.; Najarian, J.S.: Experimental renal heterotransplantation. Transplantation 4: 377-388 (1966).

8 Giles, G.R.; Boehmig, H.J.; Lilly, J.; Amemiga, H.; Takagi, H.; Coburg, A.J.; Hathaway, W.E.; Wilson, L.B.; Dixon, F.J.; Starzl, T.E.: Mechanism and modification of rejection of heterografts between divergent species. Transplant. Proc. 2: 522-537 (1970).

9 Rosenberg, J.C.; Hawkins, E.; Rector, F.: Mechanism of immunological injury during antibody mediated hyperacute rejection of renal heterografts. Transplantation 11: 151-157 (1971).

10 Linn, P.S.; Jensen, J.A.; Pardo, V.; Davies, D.; Franklin, L.: Relationship between structural and functional changes in rejecting renal xenograft. Transplant. Proc. 3: 527-530 (1971).

11 Mozes, M.F.; Gewurz, H.; Gunnarson, A.; Moberg, A.W.; Westberg, N.G.; Jetzer, T.; Najarian, J.S.: Xenograft rejection by dog and man. Transplant. Proc. 3: 531-533 (1971).

12 Mozes, M.F.; Shons, A.R.; Harris, N.S.; Merino, G.E.; Moberg, A.W.; Campos, R.A.; Najarian, J.S.: Specificity of the heteroantibody in xenograft rejection. Surg. Forum 22: 244-246 (1971).

13 Terman, D.S.; Garcia-Rinaldi, R.; McCalmon, R.; Crumb, C.C.; Mattioli, C.; Cook, G.; Poser, R.: Modification of hyperacute renal xenograft rejection after extracorporeal immunoadsorption of heterospecific antibody. Int. J. artif. Organs 2 : 35-41 (1979).

14 Kierszensbaum, F.; Budzko, D.B.: Cytotoxic effects of normal sera on lymphoid cells. Cell. Immunol. 29: 137-146 (1977).

15 Merkel, F.K.; Bier, M.; Beavers, C.D.; Meriman, W.G.; Wilson, C.; Starzl, T.E.: Modification of xenograft response by selective plasmapheresis. Transplant. Proc.3: 534-537 (1971).

16 Moberg, A.W.; Shons, A.R.; Gewurz, H.; Mozes, M.; Najarian, J.S.: Prolongation of renal xenografts by the simultaneous sequestration of preformed antibody, inhibition of complement, coagulation and antibody synthesis. Transplant. Proc. 3: 538-541 (1971).

17 Finke, E.; Lacy, P.; Ono, J.: Use of reflected green light for specific identification of islets in vitro after collagenase isolation. Diabetes 28: 612-613 (1979).

18 Terasaki, P.J.; McClelland, J.D.: Microdroplet assay of human serum cytotoxins. Nature, Lond. 204: 998-1000 (1964).

19 Ulrichs, K.; Müller-Ruchholtz, W.: MHC class II antigen expression, the various cells of normal and activated isolated pancreatic islets. Diagn. Immunol. 3: 47-55 (1985).

20 Pharmacia Fine Chemicals: Affinity chromatography. Principles and methods (Pharmacia, Örebro, Ljungföetagen 1983).

21 Hudson, L.; Hay, F.C.: Preparation of IgM on protamine Sepharose; in Hudson, Hay, Practical immunology; 2nd ed., pp. 220-222 (Blackwell Scientific, Oxford 1980).

22 Kano, K.; Milgrom, F.: Heterophile antigens and antibodies in medicine. Curr. Top. Microbiol. Immunol. 77: 43-69 (1977).

23 Springer, G.F.: Blood group and Forssman antigenic determinants shared between microbes and mammalian cells. Prog. Allergy, vol. 15, pp. 9-77 (Karger, Basel 1971).

24 Lyampert, J.M.; Danilova, T.A.: Immunological phenomena associated with cross-reactive antigens of micro-organisms and mammalian tissues. Prog. Allergy, vol. 18, pp. 423-477 (Karger, Basel 1975).

25 Bird, G.W.G.; Roy, T.C.F.: Human serum antibodies to melibiose and other carbohydrates. Vox Sang. 38: 169-171 (1980). 
26 Lewis, T.; Reid, M.; Ellisor, S.; Avog, D.R.: A glucose-dependent panhemagglutinin. Vox Sang. 39: 205-211 (1980).

27 Lalezari, P.; Jiang, A.F.; Kumir, M.; Lalezari, I.: Carbohydratespecific antibodies in normal human sera. I. Characterization of specificity for $\beta$ - $D$-glucose. Vox Sang. 47: 133-145 (1984).

28 Lalezari, P.; Jiang, A.F.: Carbohydrate-specific antibodies in normal human sera. II. Structural definition of antigenic determinants. Vox Sang. 47: 146-156 (1984).

29 Kennet, R.H.; Fairbrother, T.; Hampshire, B.; Bochner, W.F.: The specificity of naturally occurring heterophile antibodies in normal rabbit serum. Tissue Antigens 8: 29-33 (1976).

30 Schlesinger, M.; Cohen, A.; Hurvitz, D.: Inhibition by carbohydrates of the cytotoxicity of heterologous sera for mouse thymus cells. Israel J. med. Scis. 2: 616-618 (1966).

31 Rogentine, G.N.; Plocinik, B.A.: Carbohydrate inhibition studies of the naturally occurring antibody to neuraminidasetreated human lymphocytes. J. Immun. 113: 848-858 (1974).

32 Milgrom, F.; Swieczynska, Z.: Are cross-reacting natural antibodies multispecific? Int. Archs Allergy appl. Immun. 80: 200-210 (1986).

33 Sela, B.A.; Wang, J.L.; Edelman, G.M.: Antibodies reactive with cell surface carbohydrates. Proc. natn. Acad. Sci. USA 72: 1127-1131 (1975).
34 Eidinger, D.; Bello, E.; Mates, A.: The heterocytotoxicity of human serum. I. Activation of the alternative complement pathway by heterologous target cells. Cell. Immunol. 29: 174-186 (1977).

35 Betz, M.; Hänsch, G.M.; Shin, M.L.: Ehrlich ascites cells activate the alternative pathway of the human complement system. Immunobiology 166: 397-402 (1984).

36 Eidinger, D.; Gery, I.; Bello, E.: The heterocytotoxicity of human serum. II. Role of natural antibody and of the classical and alternative complement pathways. Cell. Immunol. 29: 187-194 (1977).

Received: May 18, 1987

Correspondence to: Dr. R. Laus

Department of Immunology

University of Kiel

Brunswiker Strasse 4

D-2300 Kiel (FRG) 